\title{
Diversified Education Strategies and Objectives for Advanced Tourism Talents
}

\author{
https://doi.org/10.3991/ijet.v16i20.26513 \\ Hongli Zhao \\ Wuyi University, Wuyishan, China \\ zhao13618@163.com
}

\begin{abstract}
Talents are the prerequisite for the prosperity and development of an industry. The training of advanced higher tourism talents is essential to tourism development. However, the training models of advanced tourism talents in China are highly homogenous. The competitiveness of the talents thus cultivated cannot satisfy the demand of tourism development. Therefore, it is imperative to diversify the education of advanced tourism talents. Targeting at the graduates and students from the tourism major of colleges, this paper evaluated the training status of advanced tourism talents through questionnaire survey and interview, and pointed out various problems with the current training models: the training objectives are homogenous; the curriculum is too extensive; the faculty resources are insufficient; the teaching methods are backward and too theoretical; the students lack correct positioning, hardworking spirit, professionalism, and work abilities. Based on the survey results, diversified education strategies were proposed for advanced tourism talents from three dimensions: training objectives, training process, and training outputs. Then, a talent training model that integrates industry and teaching was created, highlighting the importance of work abilities. Besides, the authors presented the design concept of diversified curriculum, and provided a diversified practice teaching system. Taking the Thai language international tour guide major of a school for example, the diversification of training objectives, process, and outputs was discussed in detail. The research results provide a good reference for improving the training effect and teaching reform of advanced tourism talents.
\end{abstract}

Keywords-advanced tourism talents, training status, diversification, education strategies, education objectives

\section{Introduction}

In recent year, Chinese people's living standards are improving, and their tourism consumption demands are growing as well; as an enduring sunrise industry, the tourism industry has taken an increasingly important position in national economy. The tourism major in colleges and university is the main front for training tourism talents, however, with the continuous expansion of enrollment, the talent training models in these schools exhibit significant homogenous tendency, and such highly similar edu- 
cation models have resulted in that the trained talents are static, semblable, and unitary [1]. In particular, at present, the tourism major graduates with a bachelor degree only have a low contribution to the development of tourism industry in China, so in order to meet the society's demand for talents, the training of advanced tourism talents needs to catch up with the development pace of tourism industry and social economy.

The higher tourism education started in China since 1979. Compared with other disciplines, the tourism discipline started later. The higher tourism education grows with the rapid development of the tourism industry in China, and many field scholars have carried out research and analysis on higher tourism industry from different perspectives [2]. For example, some scholars researched the positioning of higher tourism education at the junior, undergraduate and graduate levels from the perspective of tourism discipline construction, and analyzed the differences among them [3]. Some scholars researched the curriculum and discipline construction problems in different stages of tourism education [4]. In terms of the supply and demand of tourism talents, some scholars used sampling and survey methods and figured out the supply and demand imbalance problems in the current tourism talent market in China, they also analyzed the intrinsic reasons and gave specific solutions [5]. Some scholars theoretically and empirically researched the higher tourism education from multiple aspects, such as the talent training models, training objectives, teaching methods, teaching effect, enrollment system, and training system, etc. [6]. Some scholars conducted empirical studies on the relationship between higher tourism education and regional economic development, and put forward several training models and solution strategies for cultivating senior tourism professionals that could meet the requirements of regional economic development [7]. In terms of foreign research concerning higher tourism education, most of them are empirical studies with each region as a unit, and most of them focus on vocational training [8], such as how to apply the industryschool-research integration teaching model, or the school-enterprise cooperative teaching model, wherein the CBE model, sandwich model, TAFE model, and dual system model are all representative and mature working ability training models in foreign studies [9]. After reviewing relevant literatures, it's found that there're very few research results on how to carry out diversified education [10], to fill in this research gap, this paper aims to explore the strategies and objectives for the diversified training of advanced tourism talents.

\section{Status Quo of Advanced Tourism Talent Training}

To figure out the status quo of advanced tourism talent training in Chinese colleges and universities, and the students' and graduates' employment ideas and work abilities, this paper selected a few students and graduates of the tourism major in a province as research objects, and adopted questionnaire survey and interview methods to carry out the research. The returned valid questionnaires included 324 copies for students on the campus, and 213 copies for graduates; besides, a few teachers from the tourism schools and several employer units in the tourism industry were interviewed, the interviewees included 15 teachers and 17 representatives from employer units. 
The questionnaire and interview results were then sorted and analyzed, and the statistical results are summarized as follows:

\subsection{Curriculum setting}

Figure 1 shows the problems with the curriculum setting of the tourism major, as can be seen from the figure, $33.2 \%$ of the respondents think that the school courses emphasize theory over practice; $32.3 \%$ of them think the teaching content of courses is not updated in a timely manner, and too little content can keep pace with the development frontier of the times; moreover, $25.3 \%$ of the respondents think that the features of the discipline are not obvious enough, graduates of other majors could also do the works of their job posts, so their professional advantages are weak; and $9.2 \%$ of them think there're too many basic courses.

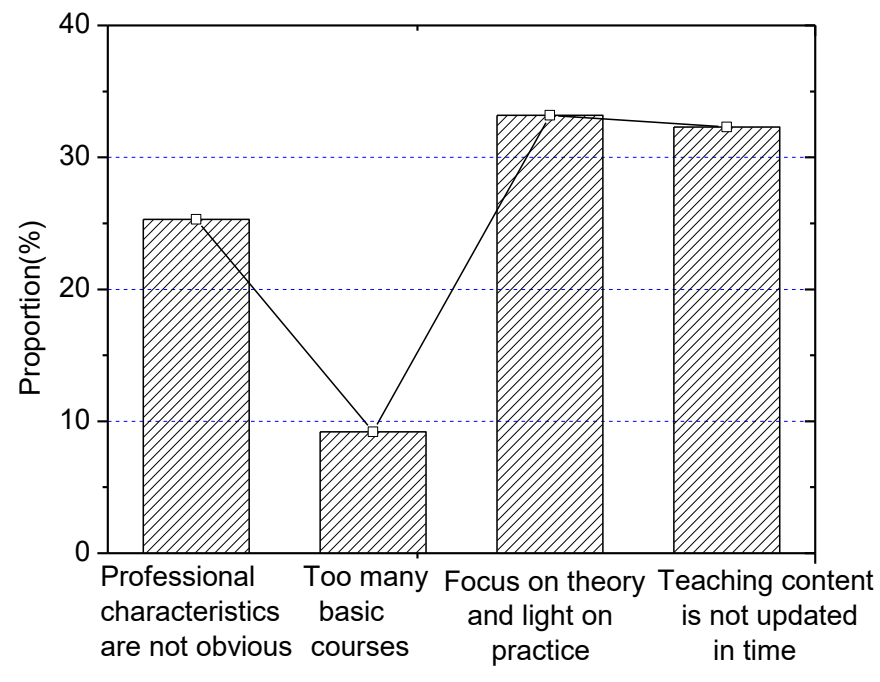

Fig. 1. Problems with the curriculum setting of tourism major

Further investigation revealed that, current higher educational schools in China have set up a variety of tourism-related majors, such as tourism management, hotel management, oversea tourism, tour guiding, and tourism service and management, etc., and their curriculum systems generally contain three parts: public basic courses, discipline basic courses, and professional courses. However, they generally emphasize basic courses over professional courses, the courses set for each major are quite similar, and the phenomenon of educational homogeneity is quite common. More than $60 \%$ of the respondents think that there's a gap between the set curriculum system and the actual market demand, although the courses can cover a wide range, there're few excellent ones. 


\subsection{Status quo of practical ability training}

Figure 2 shows the survey results of the practical ability training of tourism majors. $53.2 \%$ of the schools arrange graduation internship of a few months for students in the junior year or senior year, however, this internship method is not that helpful for students. $22.3 \%$ of the schools often arrange off-campus internship programs for students during the peak tourist seasons or after the courses are over, and this internship method is quite helpful for students. The content of the internship programs of $19.1 \%$ of the schools is quite single, most of the schools arrange students to off-campus internship bases that are in cooperation with the schools, regardless of the discipline directions of the students, their internship posts are mostly first-line service job positions such as the tour guide department, reception department, hotel reception desk, or room service department, etc. The things they learn from these posts are very limited, some students have grandiose aims but puny abilities, they are unwilling to stay in the frontline positions for too long, which is not conducive to their long-term development in the future.

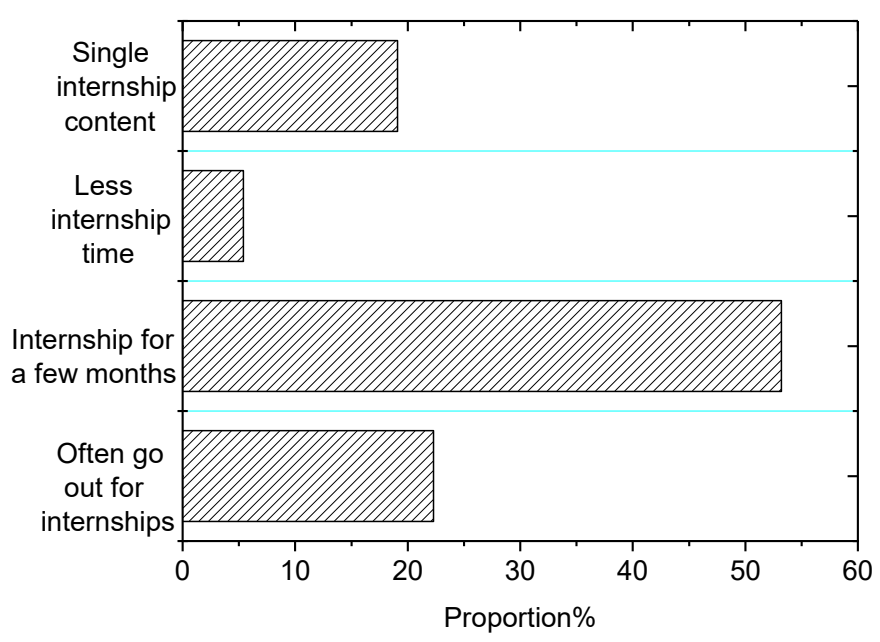

Fig. 2. Survey results of the practical ability training of tourism majors

\subsection{Employment ideas and intentions}

Figure 3 shows the results of the survey on whether students are willing to start from bottom level job positions after graduation, $55 \%$ of them are willing to do that, but the premise is that the time limit of such bottom job is within 3-6 months; $30 \%$ of them expressed that they would determine based on actual conditions of the job positions, and this indicates that most of the students would like promotion opportunities in a short time, however, this requirement is unrealistic for the tourism industry. For most of the tourism major graduates, there's no promotion opportunity after they graduate and work at the bottom level for a few years, and this is the cause of the 
talent shortage in the tourism industry. Besides, about $10 \%$ of the students said that they are unwilling to do bottom level jobs such as hotel room service or tour guides.

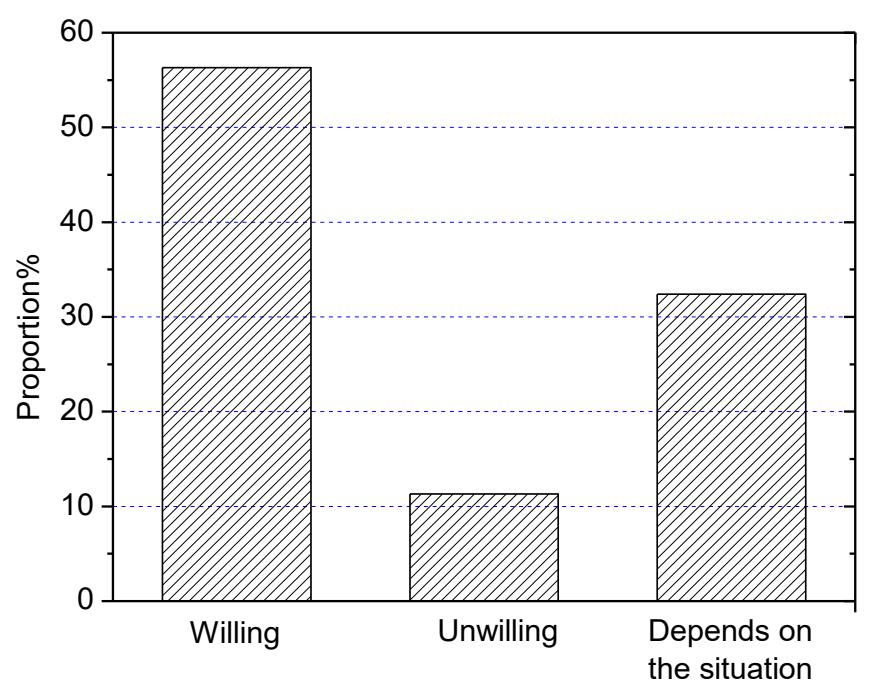

Fig. 3. Statistics of whether students are willing to start from bottom level job positions after graduation

Figure 4 shows the results of the survey on students' employment intentions after graduation. As can be seen from the figure, the homogeneous phenomenon of students' employment intentions is obvious, the top three intentions are: enterprises and institutions that are related to the tourism industry $(45.8 \%)$, enterprises and institutions that are not related to the tourism industry (45.2\%), and hotels (36.8\%). Students who chose the first two options expressed that the works in such enterprises and institutions are stable, they don't have to run around and try everything, and these job positions can win honor for them; students who chose hotels think that they can take on management positions in hotels, and the salary level and working environment in hotels are good. In addition, $30.7 \%$ of the students said that they would continue their studies, but maybe not related to the tourism industry, and they would think about pursuing a master's degree of other majors. Only a small proportion of the students chose the option of travel agency, accounting for $22.5 \%$, and these students think that they can visit a lot of places working in travel agencies. The survey results showed that, most students do not yearn for the tourism industry very much, and they prefer more stable and decent jobs. 


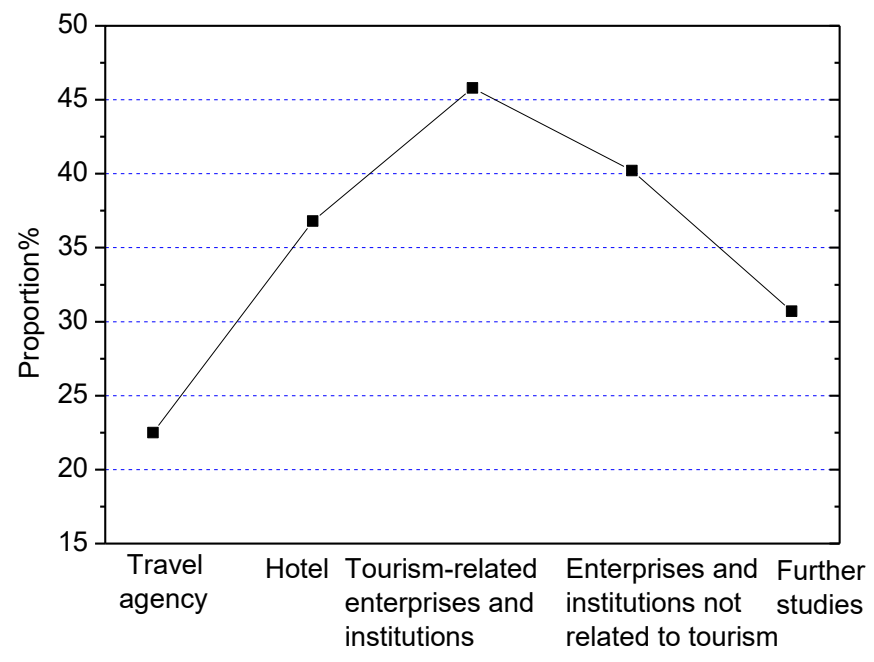

Fig. 4. Statistics of students' employment intentions after graduation

\subsection{Survey on the faculty}

Figure 5 shows the results of the survey on the main problems existing in the training of tourism talents. $42.4 \%$ of the students think that the teachers emphasize theoretical knowledge over practical knowledge; $25.87 \%$ of the students think that the teaching methods adopted by their teachers are too traditional and single, the lectures given by teachers dominate the classroom and the content is dull and tedious, students do not interest in learning, and they attend the class just to cope with the exams. Further investigation revealed that, most school teachers do not have actual working experience in the tourism industry, and there is still a certain gap between the level of the faculty and the requirement of talent training.

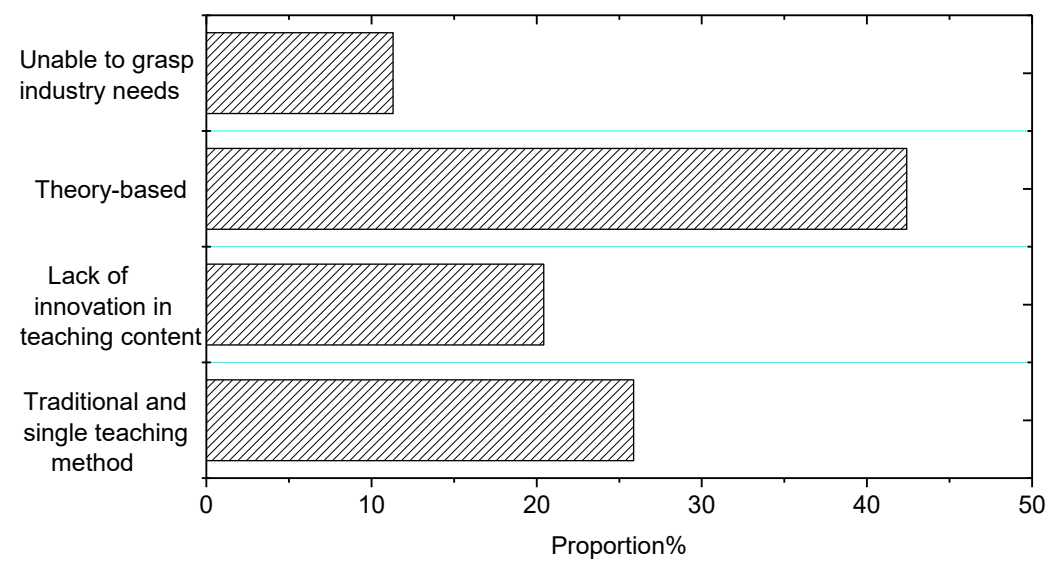

Fig. 5. Statistics of main problems existing in the training of tourism talents 
Above results showed that there're quite a few problems with the training of advanced tourism talents, including: the training objectives are homogenous; the curriculum is too extensive; the faculty resources are insufficient; the teaching methods are backward and too theoretical; the students lack correct positioning, hard-working spirit, professionalism, and work abilities. The root cause of these problems lies in the homogeneity of the training model of advanced tourism talents.

\section{Strategies and Objectives of Diversified Education for Advanced Tourism Talents}

\subsection{Strategies}

This paper proposed a few strategies for the diversified education of advanced tourism talents, see Figure 6 [11].

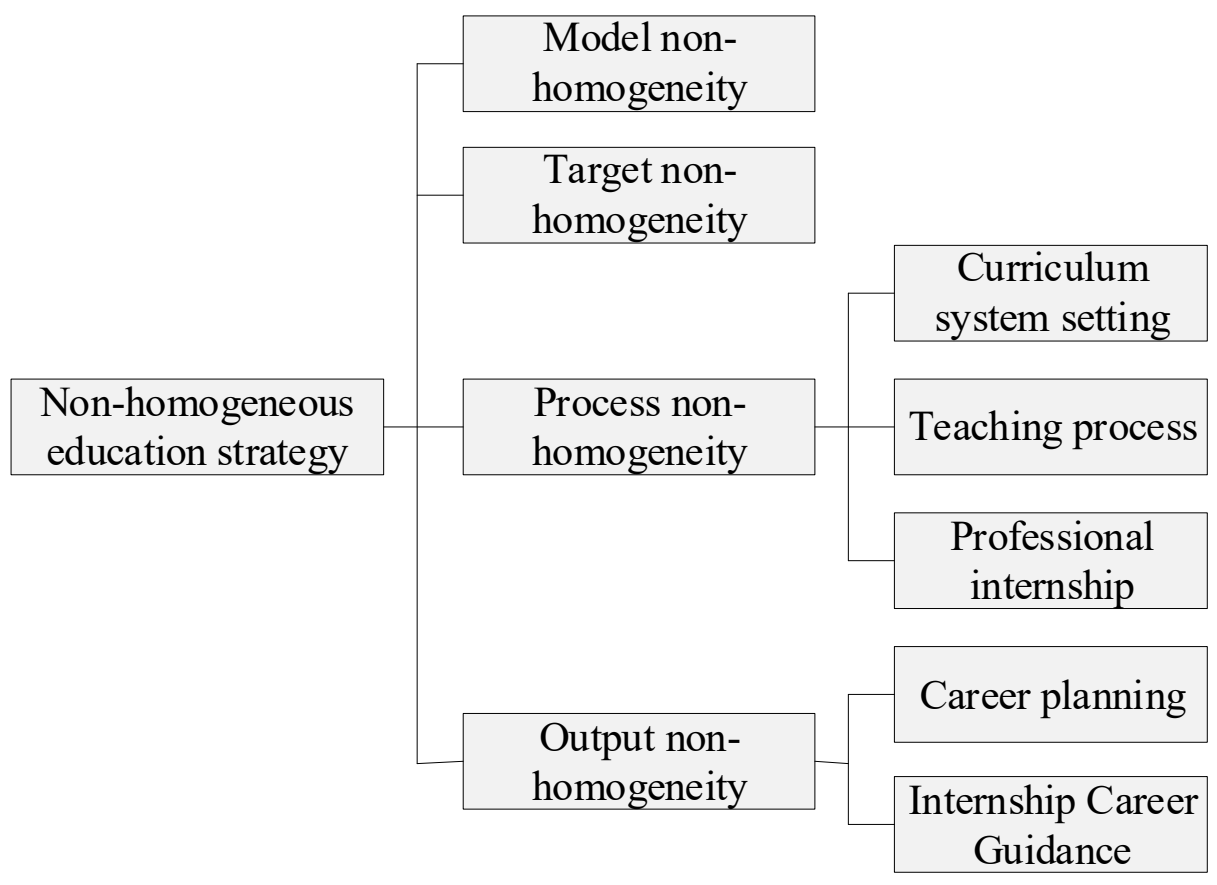

Fig. 6. Strategies for diversified education of advanced tourism talents

\subsection{The diversified talent training model}

The training of advanced tourism talents should fit the development level of regional economy, the training model should be formulated based on the talent requirements of the tourism industry, then, the talent training standards and objectives should 
be determined to ensure that the cultivated advanced tourism talents have the corresponding work abilities and are competent for the actual job positions. On this basis, this paper combined with the Canadian CBE (Competence Based Education) model [12] and constructed a diversified teaching model for the training of advanced tourism talents, as shown in Figure 7 [13]. Since most graduates will choose their works after graduation according to the principle of proximity, and the research results and the social contact scope of college teachers have obvious regional features, this teaching model emphasizes to rely on the tourism and education resources of local areas where the schools are located, break the traditional school education-centered teaching model, and carry out deep-level school-enterprises cooperative teaching model. Specifically, the schools and enterprises should formulate the talent training objectives and curriculum system based on the employee standards and requirements of the industry, and apply the competence-based industry-school cooperative talent training model [14].

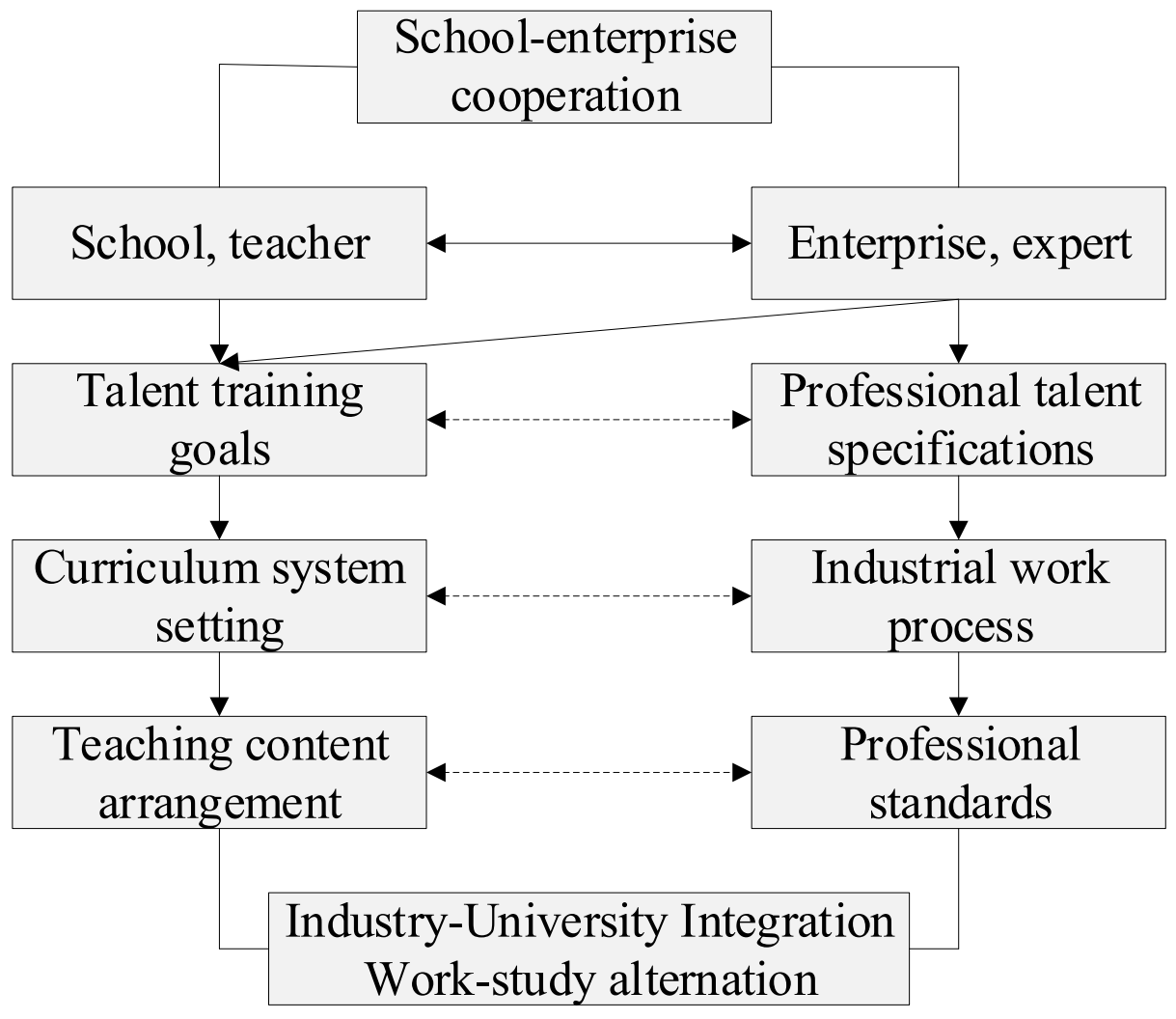

Fig. 7. A diversified teaching model for the training of advanced tourism talents 


\subsection{Diversified talent training objectives}

Now most of the tourism-related majors in Chinese colleges and universities have formulated clear talent training objectives, such as training application-type tourism management talents, innovation-type tourism management talents, or interdisciplinary tourism management talents, etc., although there're differences in the names, the required qualities and abilities of the students are basically the same and can be roughly divided into two types: the requirements of general education, and the requirements of professional education, see Table 1 for details [15]. Although these requirements are in line with the requirements of undergraduate education in solid foundation and extensive range, however, they are too general and seriously homogenous, which has resulted in a decrease in the core competence of the tourism talents. The diversified talent training objectives mean that the objectives set for the talent training should suit the talent requirements of the industry, closely follow the industrial dynamics, highlight the characteristics of the discipline, and formulate versatile professional talent training objectives that can meet the special requirements of the industry [16]. For example, a higher educational school noticed that the number of Chinese tourists traveling to Thailand has increased dramatically in recent years, so the school set up a Thai language international tour guide major combining with the regional features, and clarify its talent training objectives. Then, based these objectives, the school put more efforts into the training of students in Thai language, and knowledge about Thailand's history, culture, customs, politics, economy, and etiquette, etc., so that the students could have good Thai language listening, speaking, reading, and writing skills, and be able to use Thai language in works such as international tour guide, translation and interpretation, and teaching Chinese as a foreign language [17].

Table 1. Specific requirements for talent training

\begin{tabular}{|c|c|}
\hline Category & Claim \\
\hline $\begin{array}{l}\text { General } \\
\text { education }\end{array}$ & $\begin{array}{l}1 \text { Comprehensive development of morality, intelligence, physical fitness } \\
2 \text { Have a high level of foreign language } \\
3 \text { Have a healthy body } \\
4 \text { Have a good humanistic spirit, a scientific spirit, a sense of the times and an interna- } \\
\text { tional perspective, and a strong ability to innovate } \\
5 \text { Good information processing ability }\end{array}$ \\
\hline $\begin{array}{l}\text { Professional } \\
\text { Education }\end{array}$ & $\begin{array}{l}1 \text { Familiar with the development trends, regulations, guidelines and policies of tourism } \\
2 \text { Master the basic knowledge, basic theories and basic skills related to tourism } \\
3 \text { Able to learn independently and solve tourism-related knowledge and problems } \\
4 \text { Have the ability to apply the knowledge learned to practice } \\
5 \text { Have strong professionalism and professionalism }\end{array}$ \\
\hline
\end{tabular}

\subsection{Diversified talent training process}

The diversification of talent training process includes: the diversification of curriculum setting, the diversification of teaching process, and the diversification of professional internships [18]. 
Diversification of curriculum setting. The setting of the curriculum system is a specific manifestation of the talent training objectives. At present, the schools generally divide the courses of tourism-related majors into three types: the public basic courses, the discipline basic courses, and the professional courses; and the courses of each type can be further divided into compulsory courses and elective courses, and the specific courses are highly homogenous [19]. Taking work ability as the basis, reducing the quantity, and improving the quality are effective means to realize diversified curriculum setting; specifically, when setting up the curriculum system, the schools and teachers should work with enterprises and industry experts, and take the professional talent requirements and standards of the enterprises, and the work procedures of the industry as the orientations; they should carefully divide the work abilities required by each job position, set corresponding courses according to the requirements of the work abilities; after making sure that the students have mastered the core courses, they could trigger students' learning initiative by adding elective professional courses, or giving students more rights to choose courses on their own; in this way, the students' knowledge scope could be broadened, and a solid foundation could be built for the objectives of training talents with good knowledge basis, extensive employment prospect, and versatile abilities [20]. Again, taking the school mentioned above for example, the school and its teachers worked with enterprises and experts in the industry, based on the talent requirements of the industry, it's finally summarized that the graduates of the Thai language international tour guide major mainly have three work options after graduation, the international tour guides (in Thai language), translators and interpreters, and teachers of Chinese as a foreign language. Then, according to the work ability requirements of these job positions, the school had formulated corresponding curriculum systems, as shown in Table 2, there're mainly three categories: compulsory professional courses, elective professional courses, and optional elective courses [21].

Table 2. Curriculum system for the Thai language international tour guide major

\begin{tabular}{|l|c|}
\hline Course category & \multicolumn{1}{c|}{ Course Title } \\
\hline $\begin{array}{l}\text { Compulsory } \\
\text { professional courses }\end{array}$ & $\begin{array}{l}\text { Introduction to Tourism, Tourism Resources, Tourism Economics, Tourism Man- } \\
\text { agement, Tourism Culture, Travel etiquette, Tourism marketing, Tourism Psychol- } \\
\text { ogy, Thai Voice, Thai Intensive Reading 1-4, Thai conversation, Thai Extensive } \\
\text { Reading, Basic knowledge of tour guide, Tour guide business, General Theory of } \\
\text { Major Tourist Countries and Regions }\end{array}$ \\
\hline $\begin{array}{l}\text { Elective } \\
\text { professional courses }\end{array}$ & $\begin{array}{c}\text { Thai listening, History and Culture of Thailand, Thai computer operation, Tourism } \\
\text { Thai, Travel planning, Travel agency operation and management }\end{array}$ \\
\hline $\begin{array}{l}\text { Optional } \\
\text { elective courses }\end{array}$ & $\begin{array}{c}\text { At least 24 credits of any optional courses offered by the school according to your } \\
\text { interests, and credits of minor major will be included in the optional courses }\end{array}$ \\
\hline
\end{tabular}

Diversified teaching process. The diversification of the teaching process means that, during the teaching process, teachers change their traditional classroom lecturing teaching model, create new teaching methods, apply various teaching methods such as case study and project-based learning to the classroom teaching process, thereby realizing the activation of the teaching process [22]. The schools and teachers should take the requirements of job positions as the orientation, take the work process as the main 
line, break the original content of the chapters in the textbooks, and allow students to learn the relevant knowledge through simulated or real projects in campus training bases, professional companies, or off-campus training bases; in this way, students' ability to combine knowledge with practice could be strengthened, and their work abilities and qualities could be improved; through course learning and practical training, before graduation, they could obtain various vocational skill certificates that are related to their major, and their employment competitiveness could be greatly enhanced. Figure 8 shows the design concept of the diversified teaching process [23].

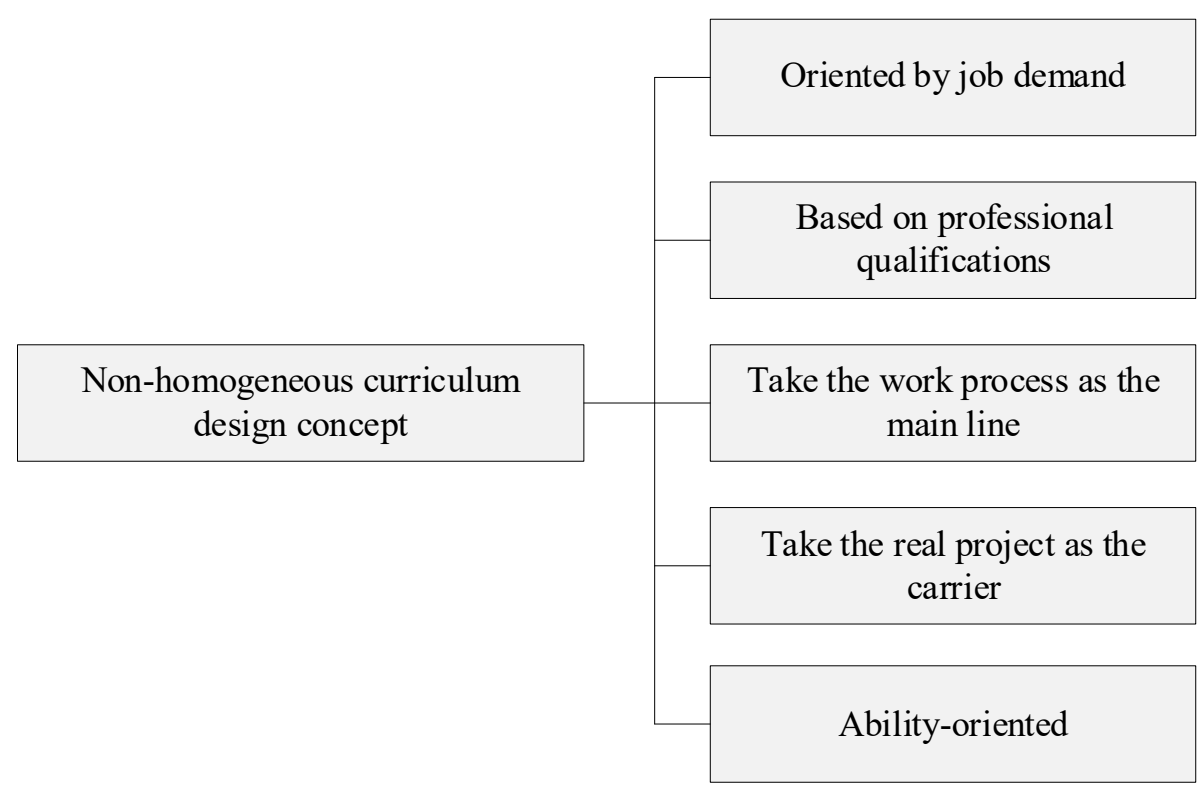

Fig. 8. Design concept of the diversified teaching process

Diversified internships. The practice teaching system is an important link in the talent training works. According to the survey results mentioned in above paragraphs, now the phenomenon of emphasizing theory over practice is quite common in the training process of tourism talents. Generally, students only concentrate on graduation internship for a few months before graduation, they have few opportunities for practice and internship during the rest of the time, as a result, they usually do not have a good understanding of the job positions in the industry, and they couldn't adapt to the talent requirements of the tourism industry. For these reasons, targeting at the status quo of tourism talent training in China and the requirements of the tourism industry, this paper designed a diversified practice teaching system, as shown in Figure 9 [24]. 


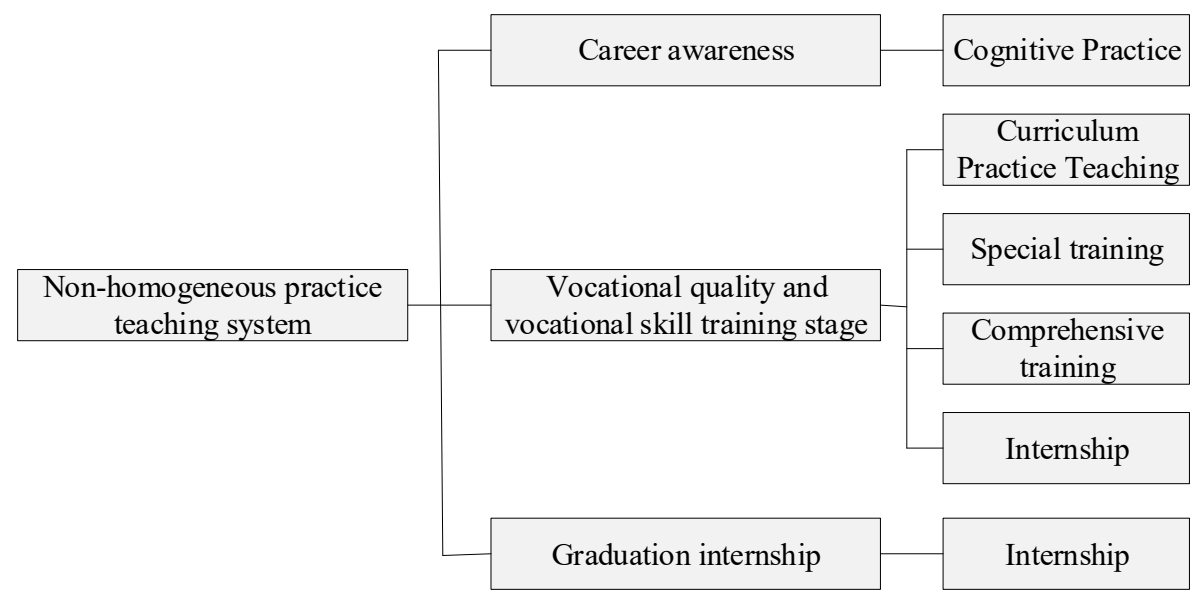

Fig. 9. The diversified practice teaching system

\subsection{Diversified talent training output}

The diversification of the output of talent training means that, based on diversified talent training models and objectives, schools need to make sure that the output talents have good professional loyalty and quality, attentions should be paid to giving proper guidance to students' career planning, specifically speaking, the schools should let students know about their major, their future job positions, and employment prospect right after they entered the school, and this is the reason why internship programs should be arranged for students to make them have a recognition of their major; moreover, schools need to instruct students to determine their future development directions based on their own advantages. The planning of career path is a longterm process, the schools need to make sure it runs through the four years of classroom teaching and internship in colleges and universities. Besides, schools should strengthen their efforts in giving instructions to students' internship and employment, help them have a correct understanding of their profession, and strengthen students' sense of professional identity. Moreover, the internship and employment guidance should not be limited to students' school years on campus, but should be extended to half a year or one year after students being employed by enterprises, in this way, we could help them smoothly get through the adaptive phase of their job positions.

\section{Conclusion}

As the tourism industry is developing rapidly in China, the market's demand for diversified talents is on the rise. In order to avoid education from being homogenous, the higher tourism schools should highlight their own advantages and features during the talent training process. On this basis, this paper researched the strategies and objectives of diversified training of advanced tourism talents, and obtained the following conclusions: 
1. Results of the survey on the status quo of the training of advanced tourism talents revealed that, currently there're a few problems existing in the training of advanced tourism talents, including: the training objectives are homogenous; the curriculum is too extensive; the faculty resources are insufficient; the teaching methods are backward and too theoretical; the students lack correct positioning, hard-working spirit, professionalism, and work abilities.

2. Based on survey results, this paper proposed a few strategies for the diversified training of advanced tourism talents from three dimensions: the talent training objectives, the talent training process, and the talent training output.

3. This paper constructed a competence-based industry-school cooperative talent training model, proposed design concepts of diversified teaching process, and designed a diversified practice teaching system. Then with the Thai language international tour guide major of a higher educational school as an example, this paper gave detailed analysis on the diversified talent training objectives, diversified talent training process, and diversified talent training output.

\section{$5 \quad$ References}

[1] Hung, K., Li, X., Pan, B., Petrick, J.F. (2010). Knowledge dissemination in tourism education: a case of tourism marketing. Journal of Travel \& Tourism Marketing, 27(5): 519-532. https://doi.org/10.1080/10548408.2010.499063

[2] Woodhouse, B., Jackson, P.H. (1977). Lower bounds for the reliability of the total score on a test composed of non-homogeneous items: ii: a search procedure to locate the greatest lower bound. Psychometrika, 42(4): 579-591. https://doi.org/10.1007/bf02295980

[3] Vila, L.E., Perez, P.J., Coll-Serrano, V. (2014). Innovation at the workplace: do professional competencies matter? Journal of Business Research, 67(5): 752-757. https://doi.org/10.1016/j.jbusres.2013.11.039

[4] Thomas, R., Wood, E. (2015). The absorptive capacity of tourism organisations. Annals of Tourism Research, 54(SEP.): 84-99. https://doi.org/10.1016/j.annals.2015.06.004

[5] Brida, J.G., Meleddu, M., Pulina, M. (2012). Understanding urban tourism attractiveness. Journal of Travel Research, 51(6): 730-741. https://doi.org/10.1177/0047287512437858

[6] Ruhanen, L., Robinson, R., Breakey, N. (2013). A tourism immersion internship: student expectations, experiences and satisfaction. Journal of Hospitality Leisure Sport \& Tourism Education, 13: 60-69. https://doi.org/10.1016/j.jhlste.2013.02.001

[7] Brooker, E., Joppe, M. (2013). Developing a tourism innovation typology. Journal of Travel Research, 53(4): 500-508. https://doi.org/10.1177/0047287513497839

[8] Savaşan, A., Yalvaç, M., Uzunboylu, H., Tuncel, E. (2017). The attitudes of education, tourism and health sector managers in northern cyprus towards education on health tourism. Quality \& Quantity, 52(S1): 285-303. https://doi.org/10.1007/s11135-017-0612-6

[9] Malhotra, N., Smets, M., Morris, T. (2016). Career pathing and innovation in professional service firms. Academy of Management Perspectives, 30(4): 369-373. https://doi.org/10. 5465/amp.2012.0108

[10] Benito, I. (2002). Documentary Resources for the Greening of Professional Training in Tourism, by J. Sureda and A. Calvo. Monografías de Educación Ambiental, Serie Documentación, Palma de Mallorca, 1998. ISBN 84-89754-40-3. International Journal of Tourism Research, 4(3): 265-266. https://doi.org/10.1002/jtr.295 
[11] Pechlaner, H., Sauerwein, E. (2002). Strategy implementation in the alpine tourism industry. International Journal of Contemporary Hospitality Management, 14(4): 157-168. https://doi.org/10.1108/09596110210427003

[12] Carmody, J. (2013). Intensive tour guide training in regional australia: an analysis of the savannah guides organisation and professional development schools. Journal of Sustainable Tourism, 21(5): 679-694. https://doi.org/10.1080/09669582.2012.744412

[13] Tolkach, D. Tung, V. (2019). Tracing hospitality and tourism graduates' career mobility. International Journal of Contemporary Hospitality Management, 31(10): 4170-4187. https://doi.org/10.1108/ijchm-10-2018-0857

[14] Watson, S. (2008). Where are we now? a review of management development issues in the hospitality and tourism sector: implications for talent management. International Journal of Contemporary Hospitality Management, 20(7): 758-780. https://doi.org/10.1108/0959 $\underline{6110810897592}$

[15] Haas, D.A., Murphy, F.H. (2003). Compensating for non-homogeneity in decision-making units in data envelopment analysis. European Journal of Operational Research, 144(3): 530-544. https://doi.org/10.1016/s0377-2217(02)00139-x

[16] Mcdonnell, I. (2000). An electronic tutorial: a teaching innovation for tourism management studies. International Journal of Tourism Research, 2(5): 367-374. https://doi.org/ 10.1002/1522-1970(200009/10)2:5\%3C367::aid-jtr238\%3E3.0.co;2-w

[17] Sigala, M. (2013). Using and measuring the impacts of geovisualisation on tourism education: the case of teaching a service management course. Journal of Hospitality Leisure Sport \& Tourism Education, 12(1): 85-98. https://doi.org/10.1016/i.jhlste.2012.11.005

[18] Simmons, D. (1989). Tourism teaching into the 1990s. Annals of Tourism Research, 16(1): 123-125. https://doi.org/10.1016/0160-7383(89)90036-4

[19] Bramwell, B. (1996). Sustainable tourism management education in europe. Tourism Management, 17(17): 307-308. https://doi.org/10.1016/0261-5177(96)87004-x

[20] Leiper, N. (2008). Why 'the tourism industry' is misleading as a generic expression: the case for the plural variation, 'tourism industries'. Tourism Management, 29(2): 237-251. https://doi.org/10.1016/j.tourman.2007.03.015

[21] Kaye, C. (2015). Tourism marketing research: current issues. Journal of travel \& tourism marketing, 32(sup1): S1. https://doi.org/10.1080/10548408.2015.1123390

[22] Zagonari, F. (2009). Balancing tourism education and training. International Journal of Hospitality Management, 28(1): 2-9. https://doi.org/10.1016/j.ijhm.2008.03.006

[23] Dale, C., Robinson, N. (2001). The theming of tourism education: a three-domain approach. International Journal of Contemporary Hospitality Management, 13(1): 30-35. https://doi.org/10.1108/09596110110365616

[24] Koh, Y.K. (1994). Tourism education for the 90s. Annals of Tourism Research, 21(4): 853-855. https://doi.org/10.1016/0160-7383(94)90096-5

\section{Author}

Hongli Zhao was born on November 7, 1974 in Wuyishan City, Fujian, China. Since August 2004, she has been a teacher of tourism management at the Tourism College of Wuyi University in Fujian Province. In 2007, she obtained a master's degree in tourism management from the School of Business Administration, Zhongnan University of Economics and Law, China. Since September 2007, she has been teaching the undergraduate courses of Introduction to China's Tourist Country of Origin and Tourism Geography, and has published more than 10 tourism-related 
papers, participated in the compilation and served as the deputy editor of a textbook, and participated in the category B of the Fujian Provincial Department of Education One social science project.

Article submitted 2021-08-21. Resubmitted 2021-09-25. Final acceptance 2021-09-29. Final version published as submitted by the author. 